\title{
Comparative Study of Lucerne (Medicago sativa L.) under Drip and Sprinkler Irrigation
}

\author{
Abdellatif Y. Idris ${ }^{1, *}$, Abdelmohsin H. El Nadi ${ }^{2}$, Yassin M.I. Dagash ${ }^{3}$, Siddig A.M.Ali ${ }^{1}$ \\ ${ }^{1}$ Department of Crop Production, Faculty of Agric., University of Zalingei, Central Darfur, P.O.Box:6 Zalingei, Sudan \\ ${ }^{2}$ Faculty of Agriculture, University of Khartoum, Khartoum North, Shambat, Postal code 31314, Sudan \\ ${ }^{3}$ College of Agricultural Studies, Sudan University of Science and Technology (Sustech.), Sudan \\ *Corresponding Author: abdalf@yahoo.com
}

Copyright (C) 2013 Horizon Research Publishing All rights reserved.

\begin{abstract}
A field experiment was conducted during the period of 2007 to 2009 in semiarid region of Khartoum State, Sudan to investigate the effect of two irrigation intervals of 8 and 12 days (W1 and W2) on growth, yield and water use efficiency (WUE) of lucerne (Medicago sativa L.) under drip and sprinkler irrigation. The daily rate of water application was $8 \mathrm{~mm}$. Therefore, the amount/irrigation was 64 and 96 $\mathrm{mm}$ for $\mathrm{W} 1$ and $\mathrm{W} 2$ respectively. The irrigation treatments were arranged in a randomized complete block design with four replications. The measured parameters were fresh and dry weights of the fodder, leaf/stem ratio and the actual water used by the crop (Etcrop) between two successive cuts. The calculated values were crop water use efficiency (WUE), field water use efficiency (FWUE) and the crop factor (kc). The results showed that the fresh and dry weights and leaf/stem ratio under $\mathrm{W} 1$ were greater than those under W2 for both irrigation systems, with superiority of these parameters under drip irrigation. WUE and FWUE under W1 with drip irrigation were always higher than those of W2 with sprinkler irrigation. The highest value for the crop factor (1.33) was during early April to late June with decreasing values during mid July to mid August.
\end{abstract}

Keywords Lucerne, Sprinkler Irrigation, Drip Irrigation, Water Use Efficiency

\section{Introduction}

The total area of forage production in Sudan is estimated to be about 126,000 ha, with almost half in Khartoum State [1]; this area is expanding with the increased attention given to dairy production, particularly around urban centers and also to satisfy the requirements of increasing animals for meat. The demand is continuously increasing due to normal population growth and mass immigration of rural communities. In addition to this, a remarkable activity for cattle and sheep for export has resulted in increasing the area of fodder crops grown primarily under irrigation.
In Sudan, lucerne is only grown under irrigation. The crop does best under sunny and dry climatic conditions. The production in irrigated areas is characterized by water deficit especially in summer. Thus, the efficient use of available water is a key to success in augmenting production of all irrigated crops.

Innovations are needed to increase the efficiency of use of available water. There are several possible approaches; one possible approach is through introducing efficient irrigation systems. Irrigation technologies and irrigation scheduling should be adopted for more effective use. Techniques like sprinkler and drip irrigation methods have proven to be most effective and feasible technology for the irrigation of some field crops including forage crops.

The present work therefore seeks to find relationships between the irrigation systems, irrigation intervals and derived or calculated values need for irrigation scheduling.

\section{Materials and Methods}

A field experiment was conducted during the period of 2007 to 2009 in the Demonstration Farm of the Faculty of Agriculture, University of Khartoum, Sudan.

The treatments were arranged in a randomized complete block design (RCBD) with four replications for both of the irrigation systems. The field was irrigated using an overhead system mounted on $1.5 \mathrm{~m}$ above the ground. The sprinkler system was made of four basic units; the pump, the main line, sprinkler lines and sprinkler heads. Spacing between the heads was $15 \mathrm{~m}$ which rotated to cover the experimental plots. High uniformity of water application was achieved by overlapping the spray from adjacent heads. The major challenges encountered during operations of the sprinkler irrigation were from wind interference and regular check for the angle of sprayers.

For the drip irrigation system, water was applied by feeders (holes) along the drip lines at spacing of $50 \mathrm{~cm}$. Lateral spacing between drip tapes was $70 \mathrm{~cm}$. Each irrigation strip had seven drip lines and was equipped with an 
inlet manifold with pressure regulator.

The frequency of fodder harvesting for all plots of lucerne was ranged between 30 - 35 days. The total number of cuts during the experimental period was 24 cut. The first cut was taken 85 days after sowing. A spring balance was used for weighting the samples in the field.

The samples for fresh weights were made on total fresh weight per plot of $16 \mathrm{~m}^{2}$ and $25 \mathrm{~m}^{2}$ for drip and sprinkler field respectively. Sub-samples from an area of one $\mathrm{m}^{2}$ were taken.

The sample used for determining the fresh weight was also used to determine dry weight. Using only sub-sample of 100 gram for oven drying for 48 hours at $70^{\circ} \mathrm{C}( \pm 1)$, the weights were expressed as ton $\mathrm{ha}^{-1}$. The water use efficiency of the crop was calculated at each plant sampling date according to Michael [2] by dividing plant dry matter (DM) weights (Ton $\left.\mathrm{ha}^{-1}\right)$ by monthly evapo-transpiration $\mathrm{Et}_{\mathrm{crop}}\left(\mathrm{cm}^{-1}\right)$ in the period between successive cuts.

FWUE expressed as $\mathrm{kg} \mathrm{ha} \mathrm{mm}^{-1}$ was obtained by dividing yield of dry matter (DM) by the total amount of water applied to the field during that period. Daily mean temperatures, hours of bright sunshine, pan evaporation, wind speed, precipitation, radiation and relative humidity during the period of the study were obtained from Shambat Meteorological Observatory about 250 meters cast of the experimental site.

Statistical analysis was performed on growth attributes, yield, and soil water data using the general linear procedures of the Statistical Analysis System [3]. The Least significant Difference (LSD) at a 0.05 probability level was used to detect the differences between treatment means.

\section{Results and Discussions}

\subsection{Forage Fresh Yield}

Yield of fresh weight obtained under irrigation every eight days $\left(\mathrm{W}_{1}\right)$ was higher than that obtained under irrigation every 12 days $\left(\mathrm{W}_{2}\right)$ (Table 1$)$. The amount delivered per day was $8 \mathrm{~mm}$ for both treatments viz, $64 \mathrm{~mm}$ and $96 \mathrm{~mm}$ per irrigation for $\mathrm{W}_{1}$ and $\mathrm{W}_{2}$ respectively. Studies of Sheaffer et al., [4] have shown that productivity is positively correlated with frequency of irrigation for lucerne. Snaydon [5] reported $50 \%$ increase in the fresh and dry matter of lucerne when light and frequent irrigations were applied compared to the production under heavy and less frequent water applications. A similar result was reported by Saeed and El Nadi [6].

The yield of fresh weight under drip irrigation was relatively higher than under sprinkler irrigation. This may be due to the fact that drip irrigation resulted in cooler temperatures on the soil surface which favored better utilization of soil water due to the more frequent wetting compared to sprinkler irrigation.

Table 1. Effect of irrigation treatments (W1 and W2) on fresh weight (ton/ha) of Lucerne during 2007

(a) Sprinkler irrigation

\begin{tabular}{|c|c|c|c|c|c|c|c|c|c|}
\hline \multirow{2}{*}{ Treatment } & Cut No. & 1 & 2 & 3 & 4 & 5 & 6 & 7 & 8 \\
\hline & Crop age (Days) & 85 & 30 & 29 & 31 & 30 & 35 & 34 & 32 \\
\hline $\mathrm{W}_{1}$ & & 10.20 & 10.01 & 10.12 & 10.13 & 10.11 & 9.14 & 7.69 & 7.70 \\
\hline $\mathrm{W}_{2}$ & & 8.49 & 8.51 & 8.49 & 8.49 & 8.49 & 7.69 & 7.59 & 7.94 \\
\hline S.E \pm & & 0.31 & 0.48 & 0.41 & 0.41 & 0.41 & 0.62 & 0.36 & 0.30 \\
\hline $\operatorname{LSD}(0.05)$ & & $0.99 *$ & 1.53 N.S & $1.30^{*}$ & $1.30 *$ & $1.30 *$ & 1.97 N.S & 1.15 N.S & 0.95 N.S \\
\hline C.V\% & & 4.63 & 7.35 & 6.20 & 6.17 & 6.17 & 10.49 & 6.69 & 5.38 \\
\hline
\end{tabular}

(b) Drip irrigation

\begin{tabular}{ccccccccccc}
\hline $\mathrm{W}_{1}$ & 11.66 & 11.60 & 11.69 & 11.65 & 11.64 & 9.38 & 7.98 & 8.94 \\
\hline $\mathrm{W}_{2}$ & 9.19 & 9.21 & 9.19 & 9.19 & 9.19 & 8.39 & 8.24 & 8.69 \\
\hline $\mathrm{S} . \mathrm{E} \pm$ & 0.72 & 0.83 & 0.82 & 0.78 & 0.77 & 1.44 & 0.65 & 0.45 \\
\hline $\mathrm{LSD}(0.05)$ & $2.29 *$ & $2.64 \mathrm{~N} . \mathrm{S}$ & $2.61 \mathrm{~N} . \mathrm{S}$ & $2.48 \mathrm{~N} . \mathrm{S}$ & $2.45 *$ & 4.58 N.S & 2.07 N.S & 1.43 N.S \\
\hline C.V\% & 9.72 & 11.23 & 11.07 & 10.58 & 10.44 & 18.23 & 11.42 \\
\hline
\end{tabular}

N.S = not statistically significant

* = significant at 0.05

$\mathrm{W}_{1}=$ irrigated every 8 days

$\mathrm{W}_{2}=$ irrigated every 12 days

Crop age of first cut in days after sowing, crop age of subsequent cuts in days after the last cut

Means followed by the same letter(s) within each column for each treatment are not significantly different at 0.05 level of probability.

Data were means of 3 years. 


\subsection{Forage Dry Yield}

The trend for dry weight was similar to that reported for fresh weight, since dry weight represented between 20 and 25 percent of the fresh weight.

Table (2) shows the effect of irrigation frequency on dry weight during 2007, 2008 and 2009. The data revealed that irrigation of lucerne every eight days $\left(\mathrm{W}_{1}\right)$ resulted in higher dry weights than irrigation every 12 days $\left(\mathrm{W}_{2}\right)$. Previous studies on the effects of irrigation on the growth and yield of lucerne indicated that the heavy, infrequent irrigation reduced stem height, stem density, leaf area index and total biomass production [6]. Recently, Saeed et al. [7] reported that the dry matter yield of lucerne irrigated every 7 and 10 days interval was higher than the yield of lucerne under 13 days interval.

The low yield per cut obtained during the months of July to September (rainy periods) is a known seasonal trend during the humid months of the year under Khartoum conditions. The peak production of lucerne during the mild month (February) when both temperature and relative humidity are low is also a known trend in semi-arid region [8].

\subsection{Leaf to Stem Ratio}

Results revealed that leaf/stem ratio under $\left(\mathrm{W}_{1}\right)$ were higher than under $\left(\mathrm{W}_{2}\right)$ for most sampling occasions during the experimental period (Fig. 1). The data clearly indicated that leaf to stem ratio inconsistently decreased with plant age throughout the experimental period. Salter et al., [9] found an increase in stem weight under condition of water stress due to increase in stem fibre and cosequently resulted in decrease in leaf/stem ratio. Leaf/stem ratio under $\left(\mathrm{W}_{1)}\right.$ was always higher than under $\left(\mathrm{W}_{2}\right)$. This shows that water stress had more adverse effect on leaf growth than the effect on the stems. Supporting evidence was found by El Amin [8] who stated that irrigation of lucerne every 13 days produced less dry weight of leaves $/ \mathrm{m}^{2}$ and consequently, reduced leaf to stem ratio compared to irrigation every 7 and 10 days. Further evidence of this fact was reported by Ludlow [10].

Plants under drip irrigation had higher leaf/stem ratio, compared to sprinkler irrigation. This was expected since the fresh and dry weights under drip irrigation were always higher than under sprinkler irrigation.

Table 2. Effect of irrigation treatments (W1 and W2) on dry weight (ton/ha) of Lucerne during 2007.

a) Sprinkler irrigation

\begin{tabular}{|c|c|c|c|c|c|c|c|c|c|}
\hline \multirow{2}{*}{ Treatment } & Cut No. & 1 & 2 & 3 & 4 & 5 & 6 & 7 & 8 \\
\hline & *Crop age (Days) & 85 & 30 & 29 & 31 & 30 & 35 & 34 & 32 \\
\hline & $\mathrm{W}_{1}$ & 3.08 & 2.86 & 2.86 & 2.73 & 2.69 & 2.68 & 2.57 & 2.16 \\
\hline & $\mathrm{W}_{2}$ & 2.83 & 2.37 & 2.42 & 2.46 & 2.60 & 2.19 & 2.20 & 2.01 \\
\hline & S.E \pm & 0.18 & 0.11 & 0.16 & 0.12 & 0.18 & 0.19 & 0.06 & 0.16 \\
\hline & $\operatorname{LSD}(0.05)$ & 0.57 N.S & $0.35 *$ & $0.51 \mathrm{~N} . \mathrm{S}$ & 0.38 N.S & 0.57 N.S & 0.60 N.S & $0.19 *$ & 0.51 N.S \\
\hline & C.V\% & 8.62 & 11.00 & 5.77 & 6.61 & 10.00 & 11.31 & 3.72 & 11.0 \\
\hline
\end{tabular}

(b) Drip irrigation

\begin{tabular}{cccccccccc}
\hline $\mathrm{W}_{1}$ & 3.12 & 3.06 & 2.96 & 2.89 & 2.84 & 2.79 & 2.57 & 2.44 \\
\hline $\mathrm{W}_{2}$ & 2.28 & 2.79 & 2.85 & 2.58 & 2.37 & 2.27 & 2.43 \\
\hline $\mathrm{S.E} \pm$ & 0.11 & 0.05 & 0.08 & 0.08 & 0.09 & 0.09 & 0.15 & 0.06 \\
\hline $\mathrm{LSD}(0.05)$ & $0.35 *$ & $0.16 *$ & $0.25 \mathrm{~N} . \mathrm{S}$ & $0.25 *$ & $0.29 *$ & $0.29 *$ & $0.48 \mathrm{~N} . \mathrm{S}$ & $0.19 *$ \\
\hline C.V\% & 5.79 & 2.52 & 3.93 & 4.32 & 4.99 & 4.93 & 8.60 & 3.72 \\
\hline
\end{tabular}

N.S $=$ not statistically significant

* = significant at 0.05

$\mathrm{W}_{1}=$ irrigated every 8 days

$\mathrm{W}_{2}=$ irrigated every 12 days

* Crop age of first cut in days after sowing, crop age of subsequent cuts in days after the last cut

** Means followed by the same letter(s) within each column for each treatment are not significantly different at 0.05 level of probability 


\subsection{Crop Water Use Efficiency (WUE)}

Water use efficiency expressed as ton $\mathrm{ha}^{-1} \mathrm{~cm}^{-1}$ (equal to ton $\mathrm{ha}^{-1} \mathrm{M}^{3} \times 100$ ) was obtained by dividing yield of dry matter $(\mathrm{DM})$ per cut by the total crop evapotranspiration $\left(\mathrm{Et}_{\text {crop }}\right)$.

WUE in ton $\mathrm{ha}^{-1} \mathrm{~cm}^{-1}$ during 2007 ranged between 0.08 and 0.17 where as during 2008 and 2009, ranged between $0.08-0.20$ and $0.08-0.21$ respectively (Fig. 2). Lucerne WUE reported in the literature ranges between 0.23 to 1.2 ton $\mathrm{ha}^{-1} \mathrm{~cm}^{-1}$ with the greater values in the cooler, more northerly climates of Sudan [6]. Abdul-Jabbar et al. [11] studied alfalfa under sprinkler irrigation and reported a range of WUE values from 0.09 to 0.14 ton $\mathrm{ha}^{-1} \mathrm{~cm}^{1}$.

Irrigation under $\mathrm{W}_{1}$ resulted in higher WUE than under $\mathrm{W}_{2}$. The average WUE for $\mathrm{W}_{1}$ was 0.10 and 0.21 . Previous studies showed that heavy, infrequent irrigation reduced WUE of Lucerne plants [6]. Kuslu et al., [12] stated that there is a linear relationship between dry matter production and water use for alfalfa. However, this relationship may vary from one climatic region to another [13], from one season to another, and from one harvest to another during the growing season [14]. The results of this study showed that Sprinkler Irrigation a

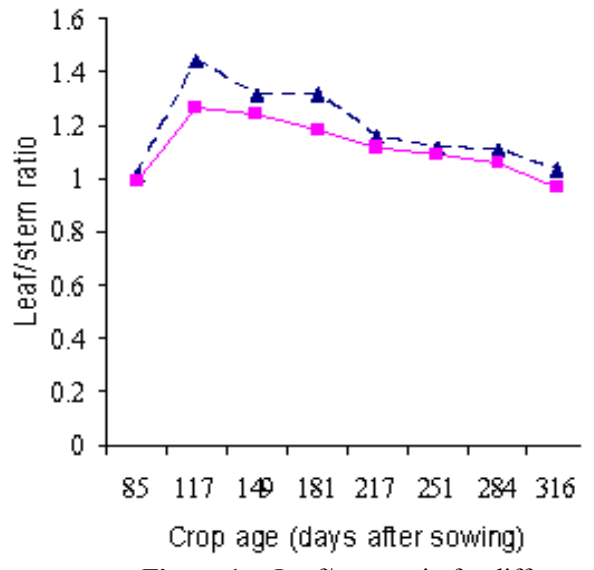

Figure 1. Leaf/stem ratio for different cuts of lucerne under sprinkler irrigation (a) and drip irrigation (b)

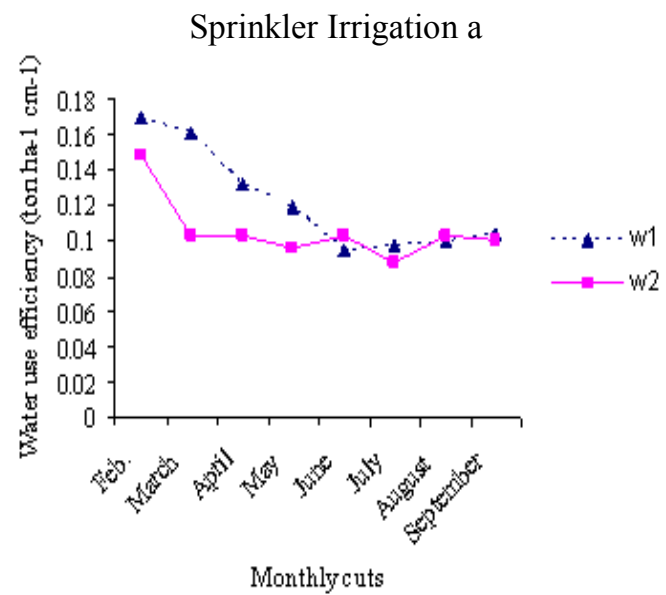

Drip Irrigation $b$

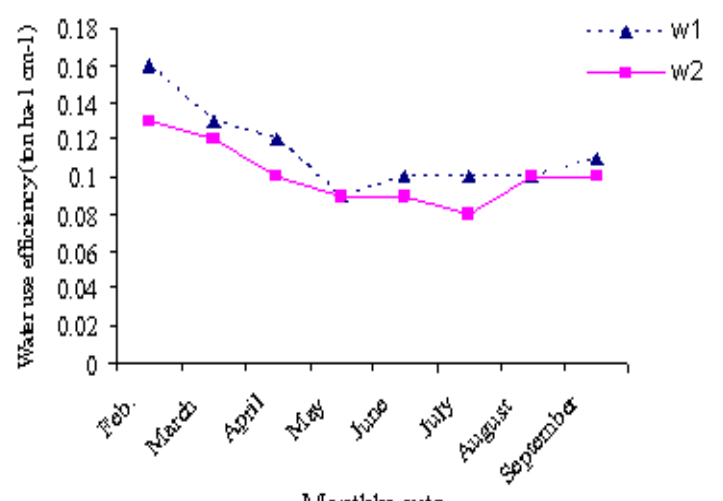

Monthly cuts

Figure 2. Water use efficiency (WUE) in ton $\mathrm{ha}^{-1} \mathrm{~cm}^{-1}$ for monthly cuts of lucerne under sprinkler (a) and drip irrigation (b) 


\subsection{Field Water Use Efficiency (FWUE)}

FWUE expressed as $\mathrm{kg} \mathrm{ha}^{-1} \mathrm{~mm}^{-1}$ (equal to $\mathrm{kg} \mathrm{ha}^{-1} \mathrm{M}^{3} \times 10$ ) was obtained by dividing yield of dry matter (DM) by the water applied during that period.

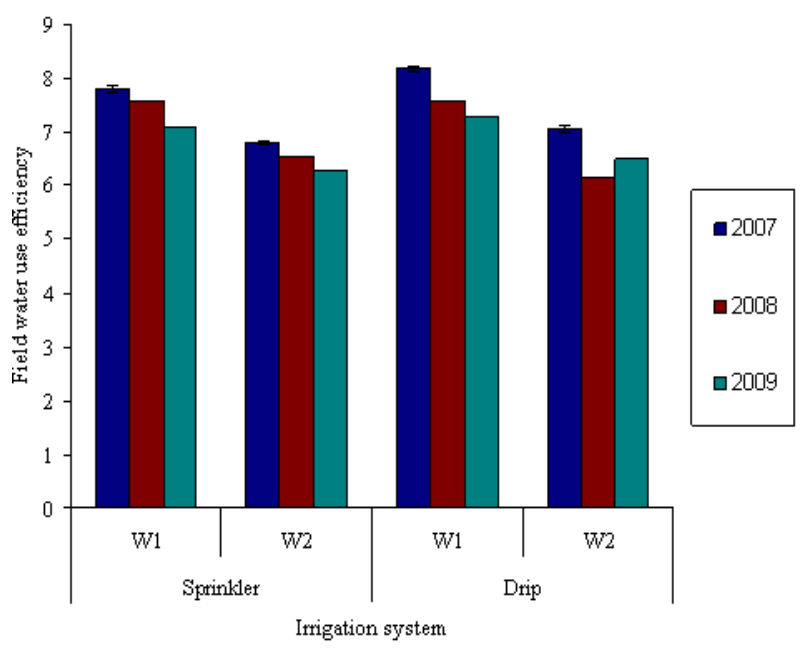

Figure 3. Field water use efficiency (FWUE) in $\mathrm{Kg} \mathrm{ha}^{-1} \mathrm{~mm}^{-1}$ of lucerne under sprinkler and drip irrigation during 2007, 2008 and 2009

As a general trend, the FWUE, under W1 is always higher than under W2 although the average water applied per day was, of course the same for all treatments (Fig. 3). The maximum FWUE (8.19) was obtained using the drip irrigation compared to sprinkler irrigation (7.81). This indicated the efficiency of drip irrigation in utilizing the irrigation water and in agrees with the finding of Battikhi and Abu-hammad [17] and Zalidis et al., [18] that the irrigation water use efficiency ranged from 8.0 to 9.1 when the crop was grown in fields using drip irrigation system. The lower FWUE values obtained under sprinkler irrigation system compared with drip irrigation was due to excessive irrigation under sprinkler and higher evaporation rates when using sprinkler irrigation.

It is clear that the crop water use efficiency (WUE) as expected, was higher than field water use efficiency (FWUE) this is due to the remaining water in the soil in case of crop water use efficiency.

\subsection{Measured and Calculated Evapo-transpiration}

The highest values for calculated $\mathrm{Et}_{\mathrm{o}}$ values were recorded during early April to late June. This is due to the high temperatures and low relative humidity during this period (Table 3). During the rainy season (mid July to mid August) values decreased with increasing relative humidity and reduced bright sunshine hours during the rainy seasons.

The results of this study showed that irrigation every 12 days $\left(\mathrm{W}_{2}\right)$ reduced crop evapo-transpiration ( $\left(\mathrm{Et}_{\text {crop }}\right)$ compared with irrigation every 8 days $\left(\mathrm{W}_{1}\right)$ under both sprinkler and drip irrigation. This result agrees with the finding of Stewart et al. [19] who reported that as the amount of applied irrigation water decreased, there was a corresponding decrease in $\mathrm{Et}_{\text {crop }}$, but at lower rate.

Under $\mathrm{W}_{1}$ the $\mathrm{Et}_{\text {crop }}$ values increased from the early growing months in February, reached maximum during July and decreased gradually during September. The increase in $\mathrm{Et}_{\text {crop }}$ values during the mid growing months (July) indicated that plants used more water to meet the demand for period of high air temperatures. Sheaffer et al., [4] found that evapo-transpiration decreased during the days following cutting of Lucerne, and this is, of course, attributed to the low leaf area which increases gradually after the monthly cut. Under Sudan conditions, the highest growth rate which is reflected in the yield per cut is usually during the cool months of the year (November to March) irrespective of the irrigation interval. The findings of this study show this fact.

Table 3. Monthly crop factor (Kc) for Lucerne during 2007, 2008 and 2009

\begin{tabular}{|c|c|c|c|c|c|c|c|c|c|c|c|c|c|}
\hline \multirow{3}{*}{$\begin{array}{l}\text { 吉 } \\
\sum\end{array}$} & \multirow{3}{*}{ 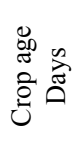 } & \multicolumn{4}{|c|}{2007} & \multicolumn{4}{|c|}{2008} & \multicolumn{4}{|c|}{2009} \\
\hline & & \multicolumn{2}{|c|}{ Sprinkler } & \multicolumn{2}{|c|}{ Drip } & \multicolumn{2}{|c|}{ Sprinkler } & \multicolumn{2}{|c|}{ Drip } & \multicolumn{2}{|c|}{ Sprinkler } & \multicolumn{2}{|c|}{ Drip } \\
\hline & & W1 & W2 & W1 & W2 & W1 & W2 & W1 & W2 & W1 & W2 & W1 & W2 \\
\hline Feb. & 85 & 0.90 & 0.96 & 0.97 & 0.91 & 0.80 & 0.67 & 0.77 & 0.81 & 0.89 & 0.91 & 0.79 & 0.82 \\
\hline March & 117 & 1.09 & 1.03 & 1.04 & 1.09 & 0.98 & 1.01 & 1.10 & 1.05 & 1.02 & 1.03 & 1.07 & 1.03 \\
\hline April & 148 & 1.02 & 1.01 & 1.07 & 1.17 & 1.23 & 1.07 & 1.24 & 1.20 & 1.06 & 1.04 & 1.22 & 1.17 \\
\hline May & 179 & 1.08 & 1.01 & 1.20 & 1.13 & 1.20 & 1.07 & 1.20 & 1.16 & 1.12 & 1.08 & 1.12 & 1.13 \\
\hline June & 210 & 1.17 & 1.08 & 1.25 & 1.10 & 1.09 & 1.10 & 1.17 & 1.09 & 1.17 & 1.19 & 1.25 & 1.17 \\
\hline July & 244 & 1.20 & 1.02 & 1.14 & 1.10 & 1.27 & 1.13 & 1.18 & 1.09 & 1.28 & 1.23 & 1.25 & 1.16 \\
\hline August & 275 & 1.29 & 1.03 & 1.19 & 1.22 & 1.19 & 1.16 & 1.24 & 1.16 & 1.29 & 1.33 & 1.21 & 1.16 \\
\hline Sep. & 306 & 1.23 & 1.11 & 1.18 & 1.21 & 1.20 & 1.20 & 1.20 & 1.20 & 1.22 & 1.25 & 1.19 & 1.14 \\
\hline Mean & & 1.12 & 1.03 & 1.13 & 1.12 & 1.12 & 1.05 & 1.14 & 1.10 & 1.13 & 1.13 & 1.14 & 1.10 \\
\hline
\end{tabular}




\subsection{Monthly Crop Factor (Kc) and Crop Water Requirements (CWR)}

The crop factor $(\mathrm{Kc})$ value of lucerne is about 0.4 just after cutting, increasing to 1.05 to 1.2 just before the next cutting with a mean value of 0.85 to 1.05 [20]. Kc values for this study ranged between $0.90-1.33$ (Table 4)

Table 4. Daily evapo-transpiration from Lucerne (mm/day) during 2007, 2008 and 2009 as determined by different methods

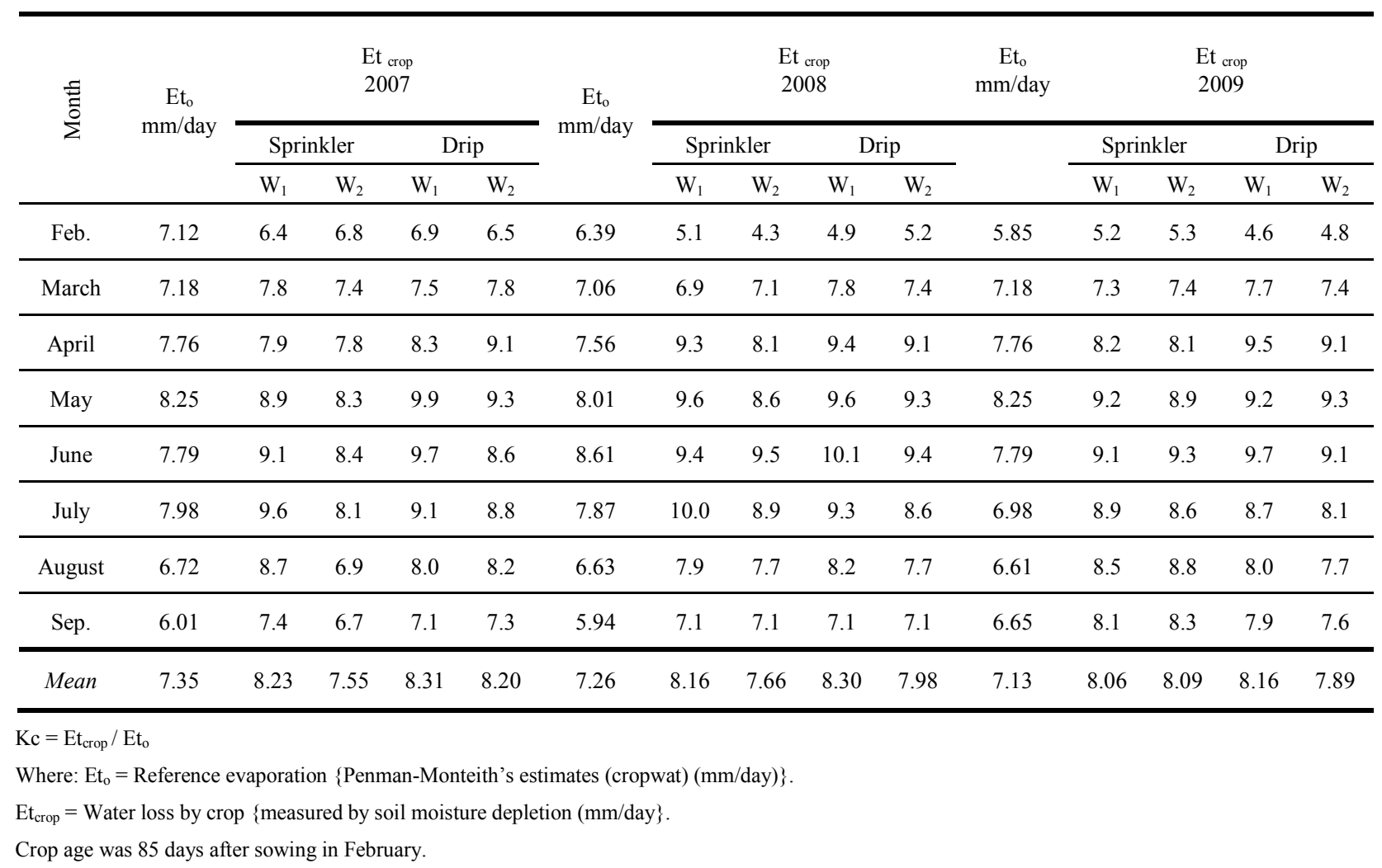

Reference [21] stated that for most crops, Kc values increased from a low value at time of crop establishment to a maximum value during the period when it reaches full leaf development and declined with maturity.

Fodder lucerne, has a new growth cycle between two successive cuts as shown in the results of this study. The value for $\mathrm{Kc}$ therefore, varies with leaf area after each cut.

The value of $\mathrm{Kc}$ was higher than unity immediately before cutting the crop (i.e. maximum leaf area) and was lowest immediately after the crop was cut. Under irrigation every 8 days $\left(\mathrm{W}_{1}\right)$ the values of $\mathrm{Kc}$ were higher than under irrigation every 12 days $\left(\mathrm{W}_{2}\right)$ due to the higher fodder yield obtained under $\mathrm{W}_{1}$. This is in accordance with the results of [22]. The values for Kc increased during the period February to June and decreased during the period July to September. The decrease in these values is attributed to the high humidity and decease in bright sunshine hours (Kharief).

\section{Conclusions}

From the results of the present study, it can reasonably be concluded that irrigation of lucerne every eight days with drip irrigation resulted in best fodder fresh and dry yields, leaf/stem ratio, Kc, WUE and FWUE. Accordingly, it is useful to use drip irrigation for lucerne fodder production. However, under semi-arid conditions, with relatively high temperatures, sprinkler irrigation can be used to reduce air temperature over lucerne canopy during the time of irrigation, i.e reduce the heat load and create favorable microenvironment for the growth and production of lucerne.

\section{Acknowledgment}

I am indebted to the University of Zalingei and German Academic Exchange Service (DAAD) for the financial support they provided for this study.

\section{REFERENCES}

[1] Zaroug, M. G.; Abul Aziz; A. M.and Mahmoud H. A. (1997). Forage and Pasture Seed Production in the Sudan: An Overview. Forage and Pasture Seed Seminar, ICARDA/ILRI.

[2] Michael, A.M. (1978). "Irrigation: Theory and Practice", Vikas Publishing House. PVT.L.T. New delhi, India.

[3] SAS Institiute (1990). SAS/STAT user's guide 1990 ed. SAS Institute, Inc. Cary, NC, USA. 
[4] Sheaffer, C.C.; Tanner, C.B. and M.B. Kirkham (1988). Alfalfa water relations and irrigation. In: A.A. Hanson, ed. Alfalfa and Alfalfa Improvement. Madison, Wisc.: American Society of Agronomy: 373-409.

[5] Snaydon, R. W. (1972). The effect of total water supply, and frequency of application, upon lucerne. I. Dry matter production. Australia Journal of Agric. Research, 23: 239-51.

[6] Saeed, I.A.M. and A.H. El Nadi (1997). Irrigation effects on the growth, yield and water used efficiency of alfalfa. Irrigation Sci., 17: 63- 68.

[7] Saeed, I.M.A.; El Amin, A.M.; Mansour, M.A.; Abdeen, E.E. and El Nadi, A.H. (2008). Optimum Water Requirements for the Commercial Production of Lucerne in Khartoum State. Crop Husbandry Committee, ARC, Wadmadani, Sudan.

[8] El Amin, A.M. (1976). Production of Lucerne under Irrigation. M.Sc. Thesis, University of Khartoum, Sudan.

[9] Salter, R.; Melton, B.; Wilson, M. and C. Currier (1984). Selection in alfalfa for forage yield with three moisture levels in drought boxes. Crop Sci. 24:345-349.

[10] Ludlow, M.M. (1989). Strategies of response to water stress. In: K.H. Kreeb, H. Richter, T.M. Hinkley, (eds). Structural and Functional Responses to Environmental Stress. The Hague, N: SPB Academic Publishing: 269-281.

[11] Abdul-Jabbar, A.S., Sammis, T.W., Lugg, D.G., Kallsen, C.E. and Smeal, D. (1983). Water use by alfalfa, corn and barley as influenced by available soil water. Agric. Water Management 6: 351-363.

[12] Kuslu, Y.; U. Shahin; T. Tunc and F. M. Kiziloglu (2010). Determining Water-Yield Relationship, Water Use Efficiency, Seasonal Crop and Pan Coefficient for Alfalfa in A Semiarid Region with High Altitude. Bulgarian J. of Agric. Sci., 16 (No 4): $482-492$

[13] Hill, R.J.; Johns, E.L. and Frevert, D.K. (1983). Comparison of equations used for estimating agricultural crop evapotranspiration with field research. USA Department of Interior, Bureau of Reclamation Tech. Rep. 08H-0808.

[14] Hansen, N. (2011). Alfalfa plant-water relations in the Great Plains and Inter- Mountain West Agronomy J. 103: 45-50.

[15] Saeed I.A.M. (1984). Comparative methods for estimation of water Requirements of fodder sorghum and lucerne. M.Sc. thesis, University of Khartoum, Sudan.

[16] Al-Jamal, M.S.; S. Ball and T.W. Sammis (2001). Comparison of sprinkler, trickle and furrow irrigation efficiencies for onion production. Agricultural Water Management 46: 253-266.

[17] Battikhi, A.M., Abu-hammad, A.H., (1994). Comparison between the efficiencies of surface and pressurized irrigation systems. Jordan. Irrig. Drain. Syst. 8: 109-121.

[18] Zalidis, G.; Dimitriads, X.; Antonopoulos, A. and Geraki, A. (1997). Estimation of a network irrigation efficiency to cope with reduced water supply. Irrigation and Drain. Syst. 11: 337-345.

[19] Stewart, B.A.; Musick, J.K.and Dusek, D.A. (1983). Yield and water use efficiency of grain sorghum in a limited irrigation-dry land farming system. Agron. J. 75: 629-634.

[20] FAO (2010). Crop Water Information: Alfalfa. Food \& Agricultural Organization, Rome, Italy. http://www.fao.org/nr/water/cropinfo_alfalfa

[21] Doorenbos, J.; Kassam, A.H.; Bentvelesn, C.L.M; Branscheid, V.; Plusje, J.M.; Vittenbognard, G.O. and Van Derwal, H.K. (1986). Yield response to water. Irrigation and Drainage Paper No. 33, FAO, Rome, Italy.

[22] Ahmed M.F. and Naim E.I. (1993). Effect of irrigation interval on consumptive use, water use efficiency and crop coefficient of Sunflower. U.K.J. Agric. Sci. 1(2): 1-15. 